\title{
Crónica de la revista Munibe Antropologia-Arkeologia 2016
}

Por primera vez en los últimos años, Munibe Antropologia-Arkeologia ha procesado dos artículos que no pudieron ser corregidos a tiempo para su edición en el número correspondiente a 2015, dentro de 2016. La fórmula de publicar en la red los artículos, con su correspondiente DOI, una vez que han superado todas las fases de evaluación, propicia una menor dependencia de la periodicidad de la edición en papel de la revista. Además de estos, otros treinta manuscritos han sido depositados en la revista para su publicación, dos de los cuales no han podido ser evaluados a tiempo en 2016 y quedan para su estudio en el próximo número, al igual que cuatro más, no han podido imprimirse por la capacidad de nuestra revista. Entre ellos, cuatro han sido rechazados finalmente, al no haber atendido sus autores suficientemente las sugerencias emitidas por los revisores externos y editores invitados correspondientes. Los restantes veintidos artículos se publican en este número de la revista.

Cada uno de los originales ha recibido un mínimo de dos revisiones externas, incorporándose en algunos casos una tercera opinión. Cuatro de estos artículos se publican tal y como fueron presentados, mientras que nueve han debido acomodarse a modificaciones severas y los trece restantes, de menor entidad. El periodo medio entre la recepción del acuso de recibo firmado por el autor de correspondencia y la emisión del informe de los revisores se sitúa en veinticinco semanas, aunque resulta muy variable en función a distintos factores como la longitud o temática del artículo.

El sistema de revisión empleado ha sido nuevamente el de doble ciego, lo que impide, tanto a los autores conocer la identidad de los revisores, como a estos, conocer la de los autores de los manuscritos evaluados. Esto ha obligado a editar cada manuscrito para eliminar cualquier rastro del / de los autores a los eventuales evaluadores: referencias de los autores, llamadas en el texto (sustituidas por la expresión "Autocita", para no romper el discurso), agradecimientos y citas bibliográficas. Todos los agentes (editores invitados, revisores externos y autores) han sido puntualmente informados por escrito de los mecanismos de evaluación que se iban a desarrollar y han dispuesto de instrucciones precisas para cada fase del proceso, incluyendo una plantilla orientativa de indicaciones de los evaluadores. En la medida de lo posible, las relaciones entre todos los agentes se han agilizado por la vía electrónica, aunque cada autor ha firmado un acuse de recibo de su original, con la fecha consignada en la cabecera de cada artículo, aceptando el protocolo aquí detallado.

El 26 de febrero de 2016 se reunió el Comité Científico de Munibe Antropologia-Arkologia, en el Palacio de la Diputación de Gipuzkoa. Como resultado de esta reunión, acordamos dar diferentes salidas a las tres propuestas de números monográficos de la cabecera Munibe An-
thropology-Archaeology Monographs depositadas en la secretaría de la revista. Una de estas propuestas, las actas que recogen la sesión A6b del Congreso de la Union Internationale des Sciences Préhistoriques et Protohistoriques (UISPP) de Burgos (The management of resources and territories in the Pyrenees from the earliest human occupation to the end of the Protohistory. A behavioural perspective) se ha incorporado al final de este número, a modo de separata de nuestra revista. También se aceptó la implantación del sistema DOI para todos los artículos de Munibe Antropologia-Arkeologia, con efectos retroactivos hasta 1983. Finalmente, se abren sendos periodos de reflexión acerca del cambio del sistema de citación de la revista y la ampliación del Comité Científico de la revista. A resultas de los mismos, el número de la revista en 2017 citará según el sistema HARVARD, adaptado a los requisitos de la red de revistas ELSEVIER. Como de costumbre, las normas de redacción estarán permanentemente actualizadas en la página web de la revista. Además, la Junta Directiva de la Sociedad de Ciencias Aranzadi aprobará, en breve, una lista de nuevos miembros del Comité Científico de Munibe Antropologia-Arkeologia.

La dotación de códigos DOI a los artículos debe mejorar su visibilidad en la red, que va mejorando sustancialmente tal y como observamos en los registros de control de Google Académico. Desde el año 1989, hasta la redacción de este texto (29 de diciembre de 2016), los diferentes artículos de Munibe Antropologia-Arkeologia (desde 1983) han sido citados 3554 veces (frente a 2905 veces el año pasado), 1702 de las cuales desde el año 2011 (por 1544 hace un año). Los artículos publicados durante el periodo 2011-2015 (95 artículos) han sido citados ya 202 veces, lo que nos proporciona el factor de impacto de la revista, para los últimos cinco años, de 2,13 citas por artículo editado. Cualquier autor puede consultar en esta aplicación el número de veces que su artículo ha sido citado y en qué contexto lo ha sido. Para el periodo reciente citado, el artículo más citado (en dieciséis ocasiones) ha sido el publicado en 2011 por P. García-Borja, D. Salazar-García, A. Pérez-Fernández, S. Pardo-Gordó y V. Casanova-Vañó, "El Neolítico antiguo cardial y la Cova de la Sarsa (Bocairent, València). Nuevas perspectivas a partir de su registro funerario".

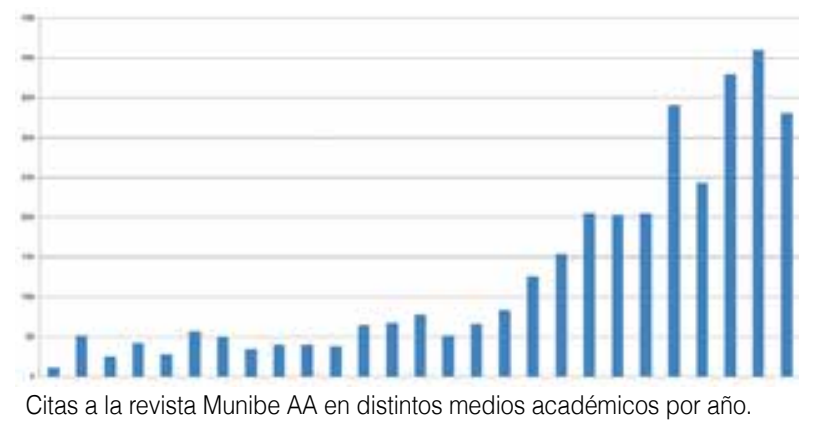


Finalmente, por cuarto año consecutivo Munibe Antropologia-Arkeologia ha tenido dos números anuales. En el mes de julio fueron publicados, en formato exclusivamente digital (on line first) los artículos evaluados y corregidos hasta esta fecha. Desde ese momento, han ido incorporándose los contenidos aceptados para su publicación en la edición en papel de la revista, hasta fin de año. En el mes de diciembre ha sido publicado el segundo número de la revista, tanto en versión digital, como en papel, aunándose en esta segunda edición los artículos de ambos números. Entre otras considera- ciones, este régimen de publicaciones implica también la desaparición de los plazos para la presentación de artículos para su evaluación, que estarán en adelante permanentemente abiertos. Obviamente, el objetivo de estos cambios es el de propiciar una mayor difusión de los contenidos editados en nuestra revista, en particular en el ámbito internacional.

Alvaro Arrizabalaga. Editor Principal 


\section{Munibe Antropologia-Arkeologia 2016 aldizkariaren kronika}

Azken urteetan lehen aldiz, Munibe Antropologia-Arkeologia aldizkariak 2015eko alerako garaiz zuzendu ezin izan ziren bi artikulu 2016an prozesatu ditu. Sarean artikuluak eta dagokien DOI identifikatzailea, ebaluazio-fase guztiak gainditu ondoren argitaratzeko erabiltzen den formulak aldizkariaren papereko edizioaren maiztasunarekiko mendekotasun txikiagoa izaten laguntzen du. Horiez gain, beste hogeita hamar idatzi ere jaso dira aldizkarian argitaratzeko. Horietako bi ezin izan dira 2016an garaiz ebaluatu eta hurrengo alerako aztergai gelditu dira. Beste lau ez dira sartu idatzizko bertsioan, ez zirelako kabitzen aurtengo alean. Lau, azkenean, atzera bota dira, egileek ez baitituzte kanpoko berrikusleek eta gonbidatutako editoreek igorritako iradokizunak behar beste aintzat hartu. Gainerako hogeita bi artikuluak aldizkariko ale honetan argitaratu ditugu.

Jatorrizko artikuluetako bakoitzak, gutxienez, kanpoko bi berrikusketa jaso ditu. Gainera, kasu batzuetan, hirugarren iritzi bat ere izan da. Artikulu horietatik lau aurkeztu zituzten moduan argitaratu ditugu. Beste bederatzik, ordea, aldaketa handiak egin behar izan dituzte eta gainerako hamahiruek, aldiz, aldaketa txikiagoak. Korrespondentziaren egileak sinatutako hartu-agiria jasotzearen eta berrikusleek txostena igortzearen arteko batez besteko epea hogeita bost aste ingurukoa da. Dena den, epe hori oso aldakorra izaten da artikuluaren luzeraren edo gaiaren moduko faktore ugarien arabera.

Erabilitako berrikusketa-sistema, beste behin, itsu bikunekoa izan da. Horren bidez, egileek ezin dute jakin zein den berrikusleen nortasuna eta berrikusleek ere ezin dute jakin zein den ebaluatutako idatzien egileen nortasuna. Hala, testuak, banan-banan, editatu egin behar izan dira ebaluatzaile izango zirenek egileen arrastorik ikus ez zezaten: egileen erreferentziak, bidaltze-markak testuan ("Autoaipua" hitza jarri dugu horrelakoen ordez), esker onak eta aipu bibliografikoak. Eragile guztiei (gonbidatutako editoreak, kanpoko berrikusleak eta egileak) eman zaie idatzizko informazioa garatu beharreko ebaluazio-mekanismoen inguruan. Gainera, prozesuaren fase bakoitzerako jarraibide zehatzak jaso dituzte, ebaluatzaileen argibideen inguruko gutxi gorabeherako txantiloia barne. Ahal izan den neurrian, eragile guztien arteko harremanak bide elektronikoaren bidez bizkortu dira, nahiz eta egile bakoitzak bere jatorrizko dokumentuaren hartu-agiria sinatu duen artikulu bakoitzaren goiburuan data kontsignatuta eta hemen zehaztutako protokoloa onartuta.

2016ko otsailaren 26an Munibe Antropologia-Arkeologiaren Batzorde Zientifikoa bildu zen Gipuzkoako Foru Aldundiko jauregian. Bilera horren emaitza gisa, aldizkariaren idazkaritzan jasotako Munibe Anthropology-Archaeology Monographs goiburuko ale monografikoen hiru proposamenei irteera ezberdinak ematea adostu genuen. Proposamen horietako bat, Union Internationale des Sciences Préhistoriques et Protohistoriques (UISSP) delakoaren Burgosko Biltzarreko A6b saioa jasotzen duten aktak (The management of resources and territories in the Pyrenees from the earliest human occupation to the end of the Protohistory. A behavioural perspective), ale honen amaieran txertatu dugu, aldizkariaren separata gisa. Munibe Antropologia-Arkeologia osatzen duten artikulu guztietan DOI sistema ezartzea ere onartu zen, 1983ra arteko atzeraeraginezko ondorioekin. Azkenik, bi hausnarketa-aldi zabaldu ziren; bat aldizkariaren aipu-sistemaren aldaketari buruz eta, bestea aldizkariaren Batzorde Zientifikoa hedatzeari buruz. Hausnarketa horien harira, aldizkariaren 2017ko alean HARVARD sistemari jarraituz egingo dira aipuak, ELSEVIER aldizkari-sarearen eskakizunetara egokituta. Ohikoa den moduan, idazteko arauak eguneratuta egongo dira beti aldizkariaren webgunean. Gainera, Aranzadi Zientzia Elkarteko Zuzendaritza Batzordeak Munibe Antropologia-Arkeologia aldizkariaren Batzorde Zientifikorako kide berrien zerrenda onartuko du laster.

Artikuluei DOI kodeak jarrita hobetu egin behar zaie artikuluei sareko ikusgarritasuna. Asko ari da hobetzen; hala erakutsi digute Google Akademikoa (Google Scholars) delakoaren kontrol-erregistroek. 1989. urtetik testu hau idatzi dugun unera arte (2016ko abenduak 29), Munibe Antropologia-Arkeologia aldizkariko artikuluak (1983. urtetik) 3.554 aldiz aipatu dira (iaz 2.905 aldiz) eta horietatik 1.7022011 tik (1.544 duela urtebete). 2011-2015 aldian argitaratutako artikuluak (95 artikulu) dagoeneko 202 aldiz aipatu izan dituzte; horrek guztiak aldizkariaren inpaktu-faktorea eskaintzen digu eta hauxe da: azken bost urteotan, argitaratutako artikulu bakoitzeko 2,13 aipu. Edozein egilek kontsulta dezake aplikazio horretan bere artikulua zenbat aldiz eta zer testuingurutan aipatu izan duten. Aipatu dugun garai horretan, aipu gehien izan dituen artikulua (hamasei aldiz) $2011 \mathrm{n}$ P. García-Borja, D. Salazar-García, A. Pérez-Fernández, S. Pardo-Gordó eta V. Casanova-Vañók argitaratutako "El Neolítico antiguo cardial y la Cova de la Sarsa (Bocairent, València). Nuevas perspectivas a partir de su registro funerario" da.

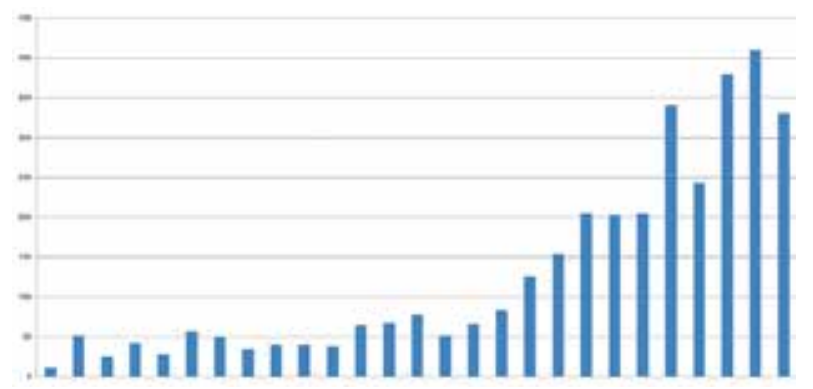

Munibe AA aldizkariaren inguruko aipuak baliabide akademiko ugaritan urte bakoitzean. 
Azkenik, laugarren urtez jarraian, Munibe Antropologia-Arkeologia aldizkariak urtean bi ale izan ditu. Uztailean, ordura arte ebaluatutako eta zuzendutako artikuluak formatu digitalean bakarrik (on line first) argitaratu genituen. Une horretatik aurrera, urtearen amaierara arte, aldizkariaren paperezko edizioan argitaratu ahal izateko onartutako edukiak gehitzen joan gara. Abenduan argitaratu dugu aldizkariaren bigarren alea, bai bertsio digitalean, bai paperean, eta bigarren argitaratze horretan bilduko dira bi aleetako artikuluak. Argita- ratzeen araubide hau ezarrita, besteak beste, desagertu egingo dira artikuluak ebaluatzera aurkezteko epeak eta hemendik aurrera, epe hori beti zabalik egongo da. Bistakoa denez, aldaketa horien helburua gure aldizkarian argitaratutako edukiei hedapen handiagoa ematea da eta, bereziki, nazioartean.

Alvaro Arrizabalaga. Editore nagusia 


\section{Chronicle of the Journal Munibe Antropologia-Arkeologia 2016}

For the first time in recent years, Munibe Antropologia-Arkeologia processed two articles which could not be corrected on time for publication in the edition corresponding to 2015, in 2016. The formula for publishing articles in the system with their corresponding DOI once they have passed all of the evaluation phases fosters less dependence on the frequency of the paper edition of the journal. In addition to these, another thirty manuscripts were deposited with the journal for publication yet two of them could not be evaluated on time in 2016 and have been left for study for the next edition. Other four have not been published because of capacity problems of our Journal. Four of them were rejected in the end as the authors did not adhere well enough to the suggestions made by the corresponding external revisers and guest editors. The remaining twenty-two articles have been published in this edition of the journal.

Each one of the originals were revised externally at least twice with a third opinion sought in some cases. Four of these articles were published as submitted while nine had to be heavily modified and the other thirteen slightly modified. The average time between the receipt of the confirmation of delivery signed by the corresponding author and the issuance of the revisers' report was twenty-five weeks although it can vary quite a bit depending on various factors such as the length or topic of the article.

The revision system used has again been double-blind which prevents the authors from knowing the identity of the revisers and the revisers from knowing that of the authors of the manuscripts they evaluate. This means each manuscript must be edited to hide any trace of the author(s) from the evaluators: author references, citations (replaced with the expression "Self-citation", so as not to break away from the discourse), words of thanks and bibliographic citations. All of the stakeholders (guest editors, external revisers and authors) have been adequately informed in writing of the evaluation mechanisms used and were given exact instructions for each phase of the process including an informational template of evaluator indications. To the extent possible, relations among all of the stakeholders were facilitated electronically although each author signed a confirmation of delivery of the original with the date indicated in the heading of each article in acceptance of the protocol outlined herein.

The Munibe Antropologia-Arkeologia Scientific Committee met on 26 February 2016 at the Provincial Government of Gipuzkoa Palace. As a result of this meeting, we agreed to facilitate different outcomes for the three proposed monographic editions of the masthead Munibe Anthropology-Archaeology Monographs deposited with the journal's secretarial office. One of these proposals, the minutes outlining session A6b of the International Union of Prehistoric and Protohistoric Sciences Congress (UISPP) of Burgos (The management of resources and territories in the Pyrenees from the earliest human occupation to the end of the Protohistory. A behavioural perspective) was included at the end of this edition as a supplement to our journal. The implementation of the DOI system for all Munibe Antropologia-Arkeologia articles was also approved with retroactive effect from 1983. Finally, it was agreed to begin reflecting upon changing the journal citation system and expanding the journal's Scientific Committee. As a result, the 2017 journal edition will be cited as per the HARVARD system, as adapted to the requirements of the ELSEVIER journal network. As is customary, the writing rules will be continuously updated at the journal's website. Moreover, the Aranzadi Science Society Governing Board will soon approve a list of new members of the Munibe Antropologia-Arkeologia Scientific Committee.

Assigning DOI codes to the articles should improve their visibility on the Internet which is substantially improving as observed through Google Scholar tracking records. From the year 1989 until the date this text was drafted (29 December 2016), the various Munibe Antropologia-Arkeologia articles (as of 1983) have been cited 3554 times (versus the 2905 recorded times last year), 1702 of them since the year 2011 (in comparison to 1544 a year ago). The articles published during the 2011-2015 period (95 articles) were already cited 202 times which reveals the journal's impact factor for the last five years as 2.13 citations per article published. Any author may consult the number of times their article has been cited and in which context via this application. For the recent period mentioned, the most-often cited article (seventeen times) was one published in 2011 by P. García-Borja, D. Salazar-García, A. Pérez-Fernández, S. Pardo-Gordó and V. Casanova-Vañó, "El Neolítico antiguo cardial y la Cova de la Sarsa (Bocairent, València). Nuevas perspectivas a partir de su registro funerario".

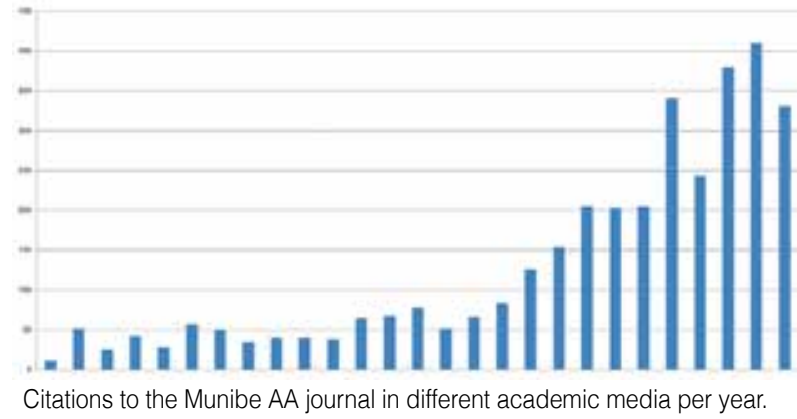


Finally, Munibe Antropologia-Arkeologia has published two annual editions for the fourth consecutive year. The articles that had been evaluated and corrected as of July were published that month exclusively in digital format (online first). After that time, the content accepted for publication in the paper edition of the journal until the end of the year was added. The second edition of the journal was published in the month of December in digital and paper formats. This second edition combined the articles from both periods. Among other consi- derations, this publication system also involves the disappearance of the deadlines for submitting articles for evaluation as acceptance will be continuous. Obviously, the purpose of these changes is to foster greater dissemination of the content published in our journal - particularly in the international arena.

Alvaro Arrizabalaga. Head Editor 